\title{
Human neutrophil alloantigens systems
}

\author{
ELYSE MORITZ, ÂNGELA M.M.I. NORCIA, JOSÉ D.B. CARDONE, SACHIE T. KUWANO, \\ AKEMI K. CHIBA, MIHOKO YAMAMOTO and JOSÉ O. BORDIN
}

Disciplina de Hematologia e Hemoterapia, Universidade Federal de São Paulo Rua Botucatu, 740, 04023-902 São Paulo, SP, Brasil

Manuscript received on September 1, 2008; accepted for publication on April 27, 2009; presented by LUIZ R. TRAVASSOS

\begin{abstract}
Neutrophil alloantigens are involved in a variety of clinical conditions including immune neutropenias, transfusionrelated acute lung injury (TRALI), refractoriness to granulocyte transfusions and febrile transfusion reactions. In the last decade, considerable progress has been made in the characterization of the implicated antigens. Currently, seven antigens are assigned to five human neutrophil antigen (HNA) systems. The HNA-1a, HNA-1b and HNA-1c antigens have been identified as polymorphic forms of the neutrophil Fc $\gamma$ receptor IIIb (CD16b), encoded by three alleles. Recently, the primary structure of the HNA-2a antigen was elucidated and the HNA-2a-bearing glycoprotein was identified as a member of the Ly-6/uPAR superfamily, which has been clustered as CD177. The HNA-3a antigen is located on a 70-95 kDa glycoprotein; however, its molecular basis is still unknown. Finally, the HNA-4a and HNA-5a antigens were found to be caused by single nucleotide mutations in the $\alpha_{\mathrm{M}}(\mathrm{CD} 11 \mathrm{~b})$ and $\alpha_{\mathrm{L}}(\mathrm{CD} 11 \mathrm{a})$ subunits of the leucocyte adhesion molecules ( $\beta_{2}$ integrins). Molecular and biochemical characterization of neutrophil antigens have expanded our diagnostic tools by the introduction of genotyping techniques and immunoassays for antibody identification. Further studies in the field of neutrophil immunology will facilitate the prevention and management of transfusion reactions and immune diseases caused by neutrophil antibodies.
\end{abstract}

Key words: neutrophil antigens, blood transfusion, alloimmunization, transfusion reaction, neutropenia.

\section{DEFINITION AND CLASSIFICATION}

Since the beginning of the twentieth century, investigators have observed that the sera of some patients caused agglutination of leucocytes from others individuals. Granulocyte antibodies have been detected in sera of multitransfused persons, women after pregnancy, patients with neutropenia, patients with febrile transfusion reactions, and in the blood of donors that caused pulmonary transfusion reactions in the transfusion recipient. The first granulocyte-specific antigen was described in 1960 by Lalezari in a case of neonatal alloimmune neutropenia. Meanwhile, a number of granulocyte antigens

In commemoration of the $75^{\text {th }}$ anniversary of Escola Paulista de Medicina / Universidade Federal de São Paulo. Correspondence to: José Orlando Bordin MD, PhD

E-mail: jobordin@hemato.epm.br has been described and characterized on the biochemical and molecular level, which allowed the development of assays for rapid antibody identification and DNA-based techniques for antigen typing (Bux et al. 1995).

Neutrophil antibodies have been shown to play a key role in the patophysiology of several clinical conditions, including neonatal alloimmune neutropenia (NAN), autoimmune neutropenia of childhood, febrile non-hemolytic transfusion reactions (FNHTR), transfusion-related acute lung injury (TRALI), immune neutropenia after bone-marrow transplantation, transfusion-related alloimmune neutropenia (TRAIN), drug-induced neutropenia, and refractoriness to granulocyte transfusion. The identification of neutrophil antigens and antibodies is relevant for the diagnosis of these disorders (Table I). 
TABLE I

Clinical conditions associated with neutrophil antibodies.

\begin{tabular}{c|c}
\hline Alloimmune diseases & Autoimmune diseases \\
\hline Neonatal alloimmune neutropenia (NAN) & Autoimmune neutropenia of childhood \\
\hline $\begin{array}{c}\text { Transfusion-related acute lung } \\
\text { injury (TRALI) }\end{array}$ & $\begin{array}{c}\text { Drug-induced immune neutropenia } \\
\text { Alloimmune neutropenia after } \\
\text { bone marrow transplantation }\end{array}$ \\
\hline $\begin{array}{c}\text { Autoimmune neutropenia after } \\
\text { bone marrow transplantation }\end{array}$ \\
\hline nransfusion-related alloimmune & \\
\hline Refractoriness to granulocyte transfusions & \\
\hline Febrile transfusion reactions & \\
\hline
\end{tabular}

TABLE II

ISBT Human neutrophil alloantigens (HNA) nomenclature.

\begin{tabular}{|c|c|c|c|c|c|}
\hline Antigen system & Carrier glycoproteins & $\mathrm{CD}$ & Antigens & Former names & Alleles \\
\hline \multirow{3}{*}{ HNA-1 } & \multirow{3}{*}{$\mathrm{Fc} \gamma$ Receptor IIIb } & \multirow{3}{*}{$\mathrm{CD} 16 \mathrm{~b}$} & HNA-1a & NA1 & $F C G R 3 B^{*} 01$ \\
\hline & & & HNA-1b & NA2 & $F C G R 3 B^{*} 02$ \\
\hline & & & HNA-1c & $\mathrm{SH}$ & $F C G R 3 B^{*} 03$ \\
\hline HNA-2 & NB1 glycoprotein & CD177 & HNA-2 & NB1 & $C D 177^{*} 01$ \\
\hline HNA-3 & unknown (GP 70-95) & & HNA-3a & $5 b$ & unknown \\
\hline HNA-4 & MAC-1; CR3; $\alpha_{\mathrm{M}} \beta_{2}$-integrin & CD11b & HNA-4a & MART & $I T G A M^{*} 01(230 G)$ \\
\hline HNA-5 & LFA-1; $\alpha_{\mathrm{L}} \beta_{2}$-integrin & CD11a & HNA-5a & OND & $I T G A L^{*} 01(2372 G)$ \\
\hline
\end{tabular}

There are several clinically important human neutrophil alloantigen systems. The nomenclature used for these antigens was established in 1998 by an International Society of Blood Transfusion (ISBT) Working Party (Bux 1999) (Table II). The antigen systems are referred to as human neutrophil antigens (HNA). This nomenclature is based on the glycoprotein location of the antigens. Different polymorphisms of the same glycoprotein are designated alphabetically, in a sequential order of detection (HNA-1a, -1b, -1c) and the nomenclature of the alleles named according to the Guidelines of the International Workshop on Human Gene Mapping. Currently, the HNA systems comprise seven antigens, which are assigned to five glycoproteins (antigen systems).

\section{HNA-1}

\section{BIOCHEMISTRY AND MOLECULAR BASIS}

The best characterized neutrophil antigen system is HNA-1, which has three alleles, HNA-1a, -1b e -1c. HNA-1a and $-1 b$ were the first granulocyte antigens described in cases of alloimune neonatal neutropenia (Lalezari et al. 1960). Later on, a third polymorphism was described, the SH antigen, now called HNA-1c (Bux et al. 1997b). HNA-1 alloantibodies can cause alloimmune neonatal neutropenia, TRALI and seem not to affect engraftment and neutrophil recovery in alloimmunized recipients of bone marrow transplants (Bux 2001) (Table III).

HNA-1 antigens are located on the human neutrophil Fc gamma-receptor IIIb (Fc $\gamma$ RIIIb) and encoded by the FCGR3B gene located on chromosome 1. Fc $\gamma$ RIIIb belongs to the immunoglobulin superfamily, as it has two extracellular disulphide-bonded immunoglobulin $\mathrm{G}$ (IgG)-like domains. The membrane proximal domain contains residues which are critical for ligand binding (Hibbs et al. 1994), and the function of the distal domain is unknown, but it is quite polymorphic. Monoclonal antibodies reacting with FcRIIIb have been designated as CD16b. The Fc $\gamma$ RIIIb is attached to the granulocyte membrane through a glycosyl-phosphatidylinositol (GPI) anchor that gives the receptor a high lateral mobility in the outer leaflet of the phospholipids bilayer 
TABLE III

Clinical disorders caused by neutrophil specific antibodies.

\begin{tabular}{l|l}
\hline Antibody & \multicolumn{1}{|c}{ Clinical condition } \\
\hline \multirow{4}{*}{ HNA-1 } & Alloimmune neonatal neutropenia \\
\cline { 2 - 2 } & Autoimmune neutropenia \\
\cline { 2 - 2 } & TRALI \\
\hline \multirow{4}{*}{ HNA-2a } & Alloimmune neonatal neutropenia \\
\cline { 2 - 2 } & Autoimmune neutropenia \\
\cline { 2 - 2 } & TRALI \\
\cline { 2 - 2 } & Drug-induced neutropenia \\
\cline { 2 - 2 } & Graft failure after bone marrow transplantation \\
\hline HNA-3a & TRALI \\
\hline \multirow{2}{*}{ HNA-4a } & Alloimmune neonatal neutropenia \\
\cline { 2 - 2 } & Autoimmune neutropenia \\
\hline HNA-5a & Unknown \\
\hline
\end{tabular}

of the plasma membrane (Huizinga et al. 1990a). The $\mathrm{Fc} \gamma$ RIIIb is a heavily glycosylated protein with different relative molecular weights of $50-65 \mathrm{kDa}$ and $65-80 \mathrm{kDa}$ for the HNA-1a and $-1 \mathrm{~b}$ isoforms, respectively (Ory et al. 1989).

Fc $\gamma$ RIIIb is the clinically most important immunogenic glycoprotein of the neutrophil membrane. In addition, $30 \%$ of granulocyte autoantibodies recognize epitopes on the Fc $\gamma$ RIIIb with a preferential binding to the HNA-1a polymorphic form of this receptor (Bux et al. 1997a). The glycoprotein is constitutively only expressed on neutrophils in mean copy numbers of 190.000 (range 120.000-400.000) (Huizinga et al. 1989).

The FCGR3B gene is located on the long arm of the chromosome 1 and consists of five exons with 699 bp encoding 233 amino acids, including a signal peptide of 17 amino acids. cDNA analysis of the gene revealed five nucleotide substitutions (nucleotides 141, 147, 227, 277 and 349) associated with the HNA-1a/b polymorphisms. All substitution sites are located in the third exon that codes for the membrane distal domain. The five nucleotide differences result in four amino acid substitutions (positions 36, 65, 82 and 106) with two additional N-linked glycosilation sites, so that the HNA-1b polymorphic form of the FCGR $3 B$ has six potential Nlinked glycosilation sites, compared to four of the HNA1a isoform. This explains the observed differences in their relative molecular weights (Ravetch and Perussia 1989).
An additional polymorphism of the $F C G R 3 B$ is the HNA- $1 \mathrm{c}$ antigen that has been associated with a later single nucleotide substitution in the allele encoding HNA1b (Bux et al. 1997a). HNA-1c genetics is complicated by the fact that some of the HNA-1c-positive individuals, mainly Europeans, possess three FCGR $3 B$ genes in their genome with a HNA-1a and -1c allele combination on the chromosome (Koene et al. 1998). An unequal crossing-over event during meiosis may be the reason for FCGR3B gene duplication in which the allele encoding HNA-1a became associated with the HNA-1c allele (Steffensen et al. 1999).

In contrast to individuals with a hiperexpression of the Fc $\gamma$ RIIIb, few individuals do not express this receptor on their neutrophils due to $F C G R 3 B$ gene deficiency, showing the HNA-1 null phenotype (de Haas et al. 1995). Most of the Fc $\gamma$ RIIIb deficient individuals do not suffer from repeated infections, autoimmune or immune complex diseases, but pregnant women can form Fc $\gamma$ RIIIbspecific alloantibodies causing alloimmune neutropenia in the neonate (Huizinga et al. 1990b).

\section{FUNCTION}

The Fc $\gamma$ RIIIb is a low affinity receptor for IgG1 and IgG3. It binds with its membrane proximal domain to the Fc parts of polymeric IgG antibodies. Resting neutrophils primarily engage $\mathrm{Fc} \gamma$ RIIIb for the binding of immune complexes and clearing them from the circulation. The receptor contributes also to the phagocytosis of opsonized micro-organisms (Bux 2008).

\section{FREQUENCY}

The HNA-1 frequencies vary widely among different populations (Kuwano et al. 2000, Kissel et al. 2000, Lin et al. 1994, Ohto and Matsuo 1989, Han and Um 1997). Using flow cytometry technique to phenotype randomly healthy Brazilian blood donors, we found a frequency of $65 \%$ and $83 \%$ for HNA- $1 \mathrm{a}$ and HNA-1b, respectively (Norcia et al. 2006) (Table IV).

\section{HNA-2}

\section{Biochemistry and Molecular Basis}

The HNA-2a antigen was described as neutrophil-specific antigen 'NB1' by Lalezari and co-workers in 1971 (Lalezari et al. 1971). HNA-2a is exclusively expressed 
TABLE IV

Human neutrophil alloantigens (HNA) frequencies (\%).

\begin{tabular}{l|c|c|c|c|c|c|c|c}
\hline Population & HNA-1a & HNA-1b & HNA-1c & HNA-1 null & HNA-2a & HNA-3a & HNA-4a & HNA-5a \\
\hline Africans & $46-66$ & $78-84$ & $23-31$ & 4 & 98 & NT & NT & 88 \\
\hline Chinese & 90 & 52 & 0 & $0-0.2$ & 99 & NT & NT & 65 \\
\hline Asian Indians & 44 & 83 & 16 & NT & NT & NT & NT & NT \\
\hline Japanese & 88 & $51-61$ & 0 & $<0.4$ & $89-99$ & NT & NT & NT \\
\hline Koreans & 78 & 75 & $<1$ & NT & 86 & NT & 99 & 96 \\
\hline Europeans & $54-52$ & $87-89$ & $5-7$ & $0.2-0.8$ & $87-97$ & $89-99$ & 96 & 96 \\
\hline North Americans & $56-62$ & 89 & 5 & NT & 97 & NT & NT & 96 \\
\hline Brazilian & 100 & 83 & 11 & NT & 97 & $86-95$ & 96 & 91 \\
\hline Brazilian Indians & 83 & 36 & 0 & NT & NT & NT & 100 & 96 \\
\hline
\end{tabular}

NT: not tested.

on neutrophils and can be found on the plasma membrane and membranes of secondary granules and secretory vesicles (Goldschmeding et al. 1992). An unique characteristic of HNA-2a is its heterogenous expression, i.e. a single individual has a neutrophil subpopulation which expresses HNA-2a and another that does not. The mean proportion of neutrophils that express HNA2a ranges from $0-100 \%$ and is slightly greater in females $(63 \%)$ than in males (53\%) (Matsuo et al. 2000, Moritz et al. 2007). The HNA-2a expression has been reported to drop in older women but not in men, suggesting that estrogen may influence the antigen expression. This is in accordance with the finding that the HNA2a expression increases in pregnancy (Caruccio et al. 2003). HNA-2a-negative individuals and the negative neutrophil subset of HNA-2a-positive individuals show in fact a null phenotype since their neutrophils are deficient in the carrier glycoprotein (Kissel et al. 2002). The alloantibodies formed by HNA-2a-negative individuals are important in neonatal alloimmune neutropenia, TRALI, autoimmune drug-induced neutropenia, and graft failure after bone marrow transplantation.

HNA-2a has been characterized as a $56-64 \mathrm{kDa}$ glycoprotein, which is like the Fc $\gamma$ RIIIb linked to the cell membrane via a GPI anchor (Stroncek et al. 1990). Monoclonal antibodies directed against HNA-2a have been clustered as CD177. The glycoprotein has two cysteine-rich domains and three $\mathrm{N}$-linked glycosylation sites. Homology of the cysteine-rich domains suggests that CD177 belongs to the Ly-6/uPAR/snake-toxin family of proteins (Kissel et al. 2001).

Kissel et al. (2001) sequenced the gene encoding HNA-2a and found it to be located on chromossome 19q13.2. In addition, there is a pseudogene homologous to exons 4 through 9 that is located adjacent to the HNA-2a gene, but oriented in the opposite direction. The HNA-2a cDNA consist of 1311 bp coding for 437 amino acids, including a signal peptide of 21 amino acids. The HNA-2a null phenotype was found to be the result of incorrect splicing, leading to mRNA strands containing intron sequences with stop codons.

\section{FUNCTION}

CD177 is involved in the adhesion of neutrophils to endothelial cells and their transendothelial migration by cationic-dependent interaction with the heterophilic domains of PECAM-1 (CD31) (Sachs et al. 2007). Recently, it has been demonstrated that the subset of neutrophils that express CD177 on their plasma membrane also displays the neutrophil serine protease proteinase 3 (mPR3), which is usually located intracellularly. The function of this co-expression of CD177 and mPR3 on the plasma membrane of a neutrophil subset is unknown (Bauer et al. 2007).

A highly significant HNA-2a up-regulation was observed in patients with bacterial infections and polycytemia vera, as well as in stem cells donors stimulated with granulocyte colony-stimulating factor (Göhring et al. 2004).

\section{FREQUENCY}

HNA-2a is a high frequency antigen in North Americans, Europeans (97\%) and Japanese (89-99.5\%). Phenotyping studies performed in our laboratory employing flow cytometry have shown that the frequency of HNA-2a in Brazilians is similar to that described by North Ameri- 
can and European studies (Lalezari et al. 1971, Moritz et al. 2007, Norcia et al. 2006, Ohto and Matsuo 1989, Tanigushi et al. 2002) (Table IV).

\section{HNA-3}

\section{BIOCHEMISTRY AND MOLECUlaR Basis}

HNA-3a antigen has been introduced by van Leeuwen et al. in 1964. It has been suggested that the antigen is located on a 70- to $95 \mathrm{kDa}$ protein, which is not linked to the plasma membrane via a GPI anchor as the HNA-1 and -2 antigens (de Haas et al. 2000). Cytogenetics studies suggested that the HNA-3a antigen is the product of a gene located on the chromossome 4 . However, the primary structure of HNA-3 remains to be elucidated.

HNA-3a is expressed on neutrophils and lymphocytes, whereas the reported expression on platelets is controversial. Alloantibodies to HNA-3a were found in occasional cases of febrile transfusion reactions (Lalezari and Bernard 1965) and neonatal immune neutropenia (de Haas et al. 2000). HNA-3a alloantibodies were increasingly reported in conjunction with TRALI, especially with severe cases, in which patients required artificial ventilation, or with fatal reactions (Davoren et al. 2003). This is possibly the result of the neutrophil priming capacity for reactive oxygen species production, and probably the marked capability of the HNA-3a antibodies to agglutinate neutrophils.

\section{FUNCTION}

Nothing is known about the function of HNA-3a.

\section{FREQUENCY}

HNA-3a is a high frequency antigen with reported phenotype frequencies ranging from $89-99 \%$ in Europeans (van Leeuwen et al. 1964, de Haas et al. 2000, Lalezari and Bernard 1965). Using flow cytometry technique, we found a HNA-3a frequency of $95 \%$ in randomly investigated healthy Brazilian blood donors (Norcia et al. 2006) (Table IV).

\section{HNA-4}

BIOCHEMISTRY AND MOLECULAR BASIS

The HNA-4a antigen and the identification of HNA4a-negative individuals were first reported in 1986 by Kline et al.
The HNA-4 system is located on the $\beta_{2}$-integrin, a member of the Leu-CAM family and integrin superfamily, which shares a common $\beta$ subunit ( $\beta_{2}$ or CD18) noncovalently associated with four different $\alpha$ subunits. The HNA-4a antigen is a polymorphic variant of $\alpha_{\mathrm{M}}$ (CR3; CD11b) subunit as the result of a single nucleotide change G302A, leading to an arginine instead of a histidine at position 61 (Simsek et al. 1996). HNA-4a alloantibodies can cause neonatal immune neutropenia (Fung et al. 2003). Two types of HNA-4a antisera have been identified, with different effects in cell interactions, suggesting that the humoral response to this antigen is heterogeneous and differs from one immunized person to another (Sachs et al. 2004). The CD11b/CD18 is also the target of autoantibodies reported not only to cause neutropenia, but also to be able to impair neutrophil adhesion (Hartman and Wright 1991).

\section{FUNCTION}

CD11b/CD18, also known as Mac-1, CR3 or $\alpha_{\mathrm{M}} \beta_{2}$ integrin, is expressed on neutrophils, monocytes and natural killer cells, and plays an important role in the leukocyte adhesion to endothelial cells and platelets, as well as in phagocytosis. It is not known whether the function of CD11b/CD18 is influenced by the HNA-4a polymorphism.

\section{FREQUENCY}

HNA-4a genotypes were found in $>90 \%$ of whites, Asians and Brazilians (Kline et al. 1986, Han and Han 2006, Cardone et al. 2006) (Table IV).

\section{HNA-5}

\section{BIOCHEMISTRY AND MOLECULAR BASIS}

The existence of a leukocyte non-HLA, now termed HNA-5a, defined by antibodies in a serum named 'OND', was reported by Decary et al. in 1979. HNA5a has been located on the $\alpha_{\mathrm{L}}$ (CD11a; LFA-1) chain of the leukocyte $\beta_{2}$-integrin family, and was found to be due to a $\mathrm{G} 2466 \mathrm{C}$ substitution in the coding sequence predicting the amino acid change Arg776Thr (Simsek et al. 1996). HNA-5a alloantibodies have not yet been involved in neutropenia. 


\section{FUNCTION}

The CD11a/CD18 complex, also known as LFA-1 or $\alpha_{\mathrm{M}} \beta_{2}$-integrin, is expressed on all leucocytes and function as a leucocyte adhesion molecule. It is unknown whether the integrin function is influenced by the HNA5a polymorphism.

\section{FREQUENCY}

Genotyping resulted in HNA-5a frequencies between $79 \%$ and $88 \%$ in different populations (Sachs et al. 2005). We have found a higher frequency of HNA-5a positive genotype in Brazilian blood donors (91\%), and Brazilian Amazon Indians (96\%) (Cardone et al. 2006) (Table IV).

\section{LABORATORIAL ASSAYS FOR DETECTING NEUTROPHIL ANTIGENS AND ANTIBODIES}

PHENOTYPING AND GENOTYPING

of NeUtrophil ANTIGENS

Traditionally, neutrophil antigen phenotyping has been performed using human alloantibodies in the granulocyte agglutination test (GAT), or the granulocyte immunofluorescence test (GIFT). However, alloantisera specific to neutrophil antigens are not always available. Alloantibodies to HNA-1a, $-1 \mathrm{~b},-2 \mathrm{a}$, and $-3 \mathrm{a}$ are available, but antibodies to HNA-1c, $-4 \mathrm{a}$, and $-5 \mathrm{a}$ are difficult to obtain.

We have found that, when used in flow cytometry, the neutrophil alloantibodies allow a higher sensitivity rate do detect HNAs when compared to the GIFT (A.M. Norcia et al., unpublished data). The GAT and GIFT assays require training, as the results are evaluated with a microscope rather than by the flow cytometer.

Monoclonal antibodies specific to HNA-1a, $-1 \mathrm{~b}$ and -2a have been described, are commercially available, and have been used to phenotype neutrophils using flow cytometry. This method is faster and easier, since the assay can be done with the whole blood instead of isolated neutrophils.

Genotyping assays to HNA-1a, -1b, -1c, $-4 \mathrm{a}$ and $-5 \mathrm{a}$ have been developed. The characterization of the genes encoding the HNA-1 antigens has allowed for the development of genotyping assays for these antigens (Bux et al. 1995, Kissel et al. 2000). HNA-1a, HNA-1b and HNA-1c are encoded by $F C G R 3 B^{*} 1, F C G R 3 B^{*} 2$ and FCGR3B*3, respectively. FCGR3B*1 and FCGR3B*2 differ at 5 nucleotides, one of which is silent. One nucleotide differs between FCGR3B*2 and FCGR3B*3. Although distinguishing single nucleotide polymorphisms is usually simple, genotyping for $F C G R 3 B$ alleles is complicated by the high degree of homology between $F C G R 3 B$ and the gene that encodes Fc $\gamma$ RIIIa, $F C G R 3 A$. Among the 5 nucleotides that differ between $F C G R 3 B^{*} 1$ and $F C G R 3 B^{*} 2, F C G R 3 A$ is the same as $F C G R 3 B^{*} 1$ at 3 nucleotides and the same as $F C G R 3 B^{*} 2$ at 2 nucleotides (Stroncek 2004). As a result most laboratories, including ours, have employed PCR-SSP to distinguish FCGR3B alleles (Fig. 1).

A

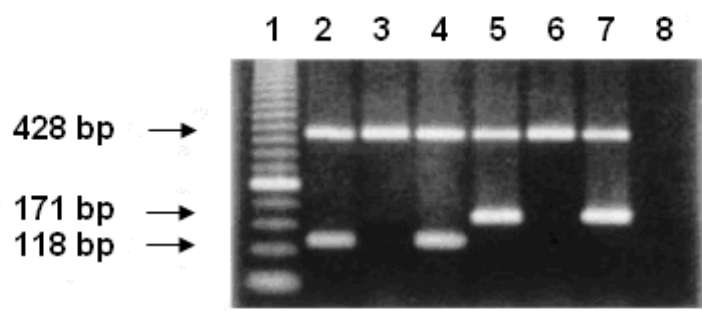

B

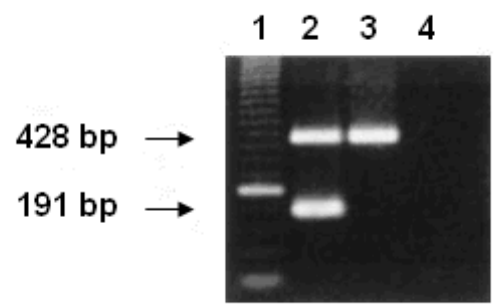

Fig. 1 - Example of HNA-1a, -1b genotyping determination by PCRSSP. The human growth hormone PCR product (428 bp) is present in all reactions. (A) Lane 1 represents the 50 bp DNA ladder; Lanes 2 and 4: 118 bp PCR product obtained with HNA-1a primers; Lanes 5 and 7: $171 \mathrm{bp}$ PCR product obtained with HNA-1b primers; Lanes 2 and 3: HNA-1a $(+/+)$ homozygous person; Lanes 4 and 5: HNA-1a (+/-) heterozygous subject; and Lanes 6 and 7 show a HNA-1b (+/+) homozygous person; Lane 8 represents the negative control. (B) Lane 1: 50 bp DNA ladder; Lane 2: PCR-SSP positive for the FCGR $3 B^{*} 3$ allele (HNA-1c); Lane 3: HNA-1c negative reaction; Lane 4: negative control (Kuwano et al. 2000).

Methods to genotype neutrophil antigens HNA-4a and -5a have been described (Simsek et al. 1996). Both of these polymorphisms are due to a single nucleotide 
polymorphism. HNA-4a is due to a single nucleotide substitution in the $\alpha_{\mathrm{M}}$ subunit of the $\beta_{2}$ integrin, G302A, which predicts an Arg61His amino acid polymorphism. HNA-5a is the result of a single nucleotide substitution in the $\alpha_{\mathrm{L}}$ subunit of the $\beta_{2}$ integrin, G2466C, which predicts an Arg766Thr amino acid polymorphism. A variety of methods can be used to type these alleles. A PCRSSP method is being used to type HNA-4a (Clague et al. 2003). HNA-5a can be typed using a PCR-SSP method or, alternatively by a PCR-RFLP method described by our group (Cardone et al. 2006) (Fig. 2).
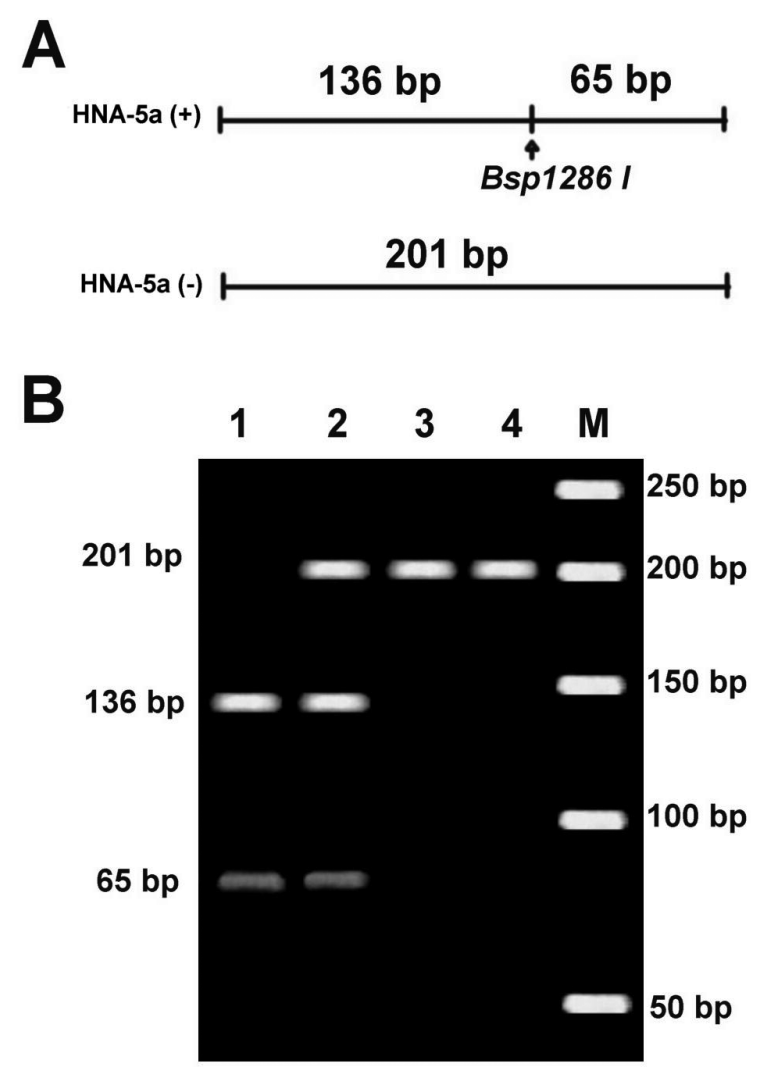

Fig. 2 - Example of PCR-RFLP method and typical results of HNA5a genotyping. (A) Region (201 bp) in the genomic DNA, in which the HNA-5a polymorphism is located, was amplified by PCR. The sizes of the fragments produced by digestion with $B s p 12861$ are shown. (B) Typical RFLP patterns Bsp12861-treated PCR product. Lane 1: homozygous HNA-5a (+/+); Lane 2: heterozygous HNA5a (+/-); Lane 3: homozygous HNA-5a (-/-); Lane 4: not digested; Lane M: 50 bp DNA ladder (Cardone et al. 2006).

Although the molecular basis of HNA-2a has already been described, HNA-2a genotyping methods are not available, yet. The HNA-2a-negative phenotype is due to CD177 mRNA splicing defects (Kissel et al. 2002). The CD177 mRNA from people with HNA2a-negative neutrophils contains additional sequences of varying length that are homologous to $C D 177$ intron sequences. However, no mutations have been detected in the $C D 177$ introns or exons from people with a negative phenotype. It may be possible to distinguish the HNA-2a-positive from HNA-2a-negative phenotypes by analyzing neutrophil CD177 mRNA for accessory sequences, but working with mRNA is much more difficult than working with DNA, and no laboratory is currently analyzing granulocyte mRNA to assess HNA-2a antigen expression.

Because the gene encoding HNA-3a has not been identified, no genotyping assays is available for this antigen.

\section{NeUtrophil ANTIBodies}

Screening for neutrophil antibodies remains technically challenging. No single technique has thus far been shown to consistently detect all clinically relevant granulocyte antibodies.

The assays used to detect neutrophil antibodies are GAT, GIFT or flow cytometry, and monoclonal antibody immobilization of granulocyte antigens (MAIGA). In the GAT, antibodies cause neutrophils to actively agglutinate (McCullough et al. 1988). It is a very reliable assay, but less sensitive than other methods. The GAT can detect antibodies to HNA-1, -2, -3, -4, and -5 antigens, and it is the assay that can best identify antibodies specific for HNA-3a.

In the microscopic GIFT, antigen-antibody reactions are detected using fluorescence-conjugated secondary antibodies and a fluorescent microscope (McCullough et al. 1988). Strong reactions are readily distinguished, but considerable training is required to distinguish weak reactions from background staining. Testing for neutrophil antibodies with flow cytometry is the same as the GIFT, except that neutrophils are evaluated with a flow cytometer rather than a fluorescence microscope.

The MAIGA assay allows the detection of antibodies to specific neutrophil membrane glycoproteins (Bux et al. 1993). It can be used to detect antibodies specific to HNA-1a, $-1 \mathrm{~b}$, and $-1 \mathrm{c}$ antigens on Fc $\gamma$ RIIIb (CD16), 
HNA-2a on NB1gp (CD177), HNA-4a on complement component $\mathrm{C} 3$ bi receptor (CR3 or CD11b), and HNA$5 \mathrm{a}$ on leukocyte function antigen-1 (LFA-1 or CD11a). The use of neutrophils from panels of donors with known HNA-1 phenotypes allows the identification of antibodies specific to HNA-1a, $-1 \mathrm{~b}$, and $-1 \mathrm{c}$. In addition, antibodies that are directed to $\mathrm{Fc} \gamma \mathrm{RIIIb}$, but are not specific to HNA-1 antigens, are sometimes detected. The MAIGA assay permits the recognition of antibodies to specific neutrophil glycoproteins even when antibodies to HLA antigens are present.

Because the gene encoding HNA-3a has not been identified, recombinant technology cannot be used to produce HNA-3a antigen. As a result, most laboratories are using intact neutrophils for antibody screening assays. Unfortunately, neutrophils have a short life span, so fresh neutrophils must be prepared from fresh whole blood using density gradient separation. Patient sera are tested against panels of neutrophils prepared from donors with known phenotypes to distinguish antibodies with different specificities. The presence of HLA antibodies can make the detection of neutrophil antibodies difficult. HLA-specific antibodies can be separated from neutrophil-specific antibodies by absorbing serum with platelets (Sachs et al. 2005). Alternatively, monoclonal antibody capture assays can be used to test for antibodies specific to neutrophil membrane glycoproteins. Mammalian cell expression systems have been used to express HNA-1a, HNA-1b and HNA-2a, and these can be used to assess antibodies in flow cytometry, but these cells are not commercially available.

\section{CONCLUSIONS}

During the last years, considerable progress has been made in the characterization of granulocyte antigens. Glycoprotein location of the antigens allowed the development of the antigen-specific MAIGA. Elucidation of their molecular basis now makes genotyping by PCRSSP possible. However, our understanding of the biochemical and molecular nature of neutrophil antigens is still incomplete and many questions remain: the clinical significance of HNA-5 is not known, characterization of the HNA-1 group is not yet complete, detailed description of the HNA-2 antigen is ongoing, and characterization of the HNA-3a antigen is just beginning.
There are many barriers to neutrophil antibody testing, including limited availability of reagent, lack of commercially available test kits, and the need to use fresh neutrophils. However, neutrophil antibodies remain clinically important and there are only few laboratories specialized in granulocyte immunology; therefore, not all cases of alloimmune neutropenia are probably investigated. Further studies in the field of neutrophil immunology will improve our diagnostic tools, and will consequently facilitate the prevention and management of transfusion reactions and immune diseases caused by neutrophil antibodies.

\section{ACKNOWLEDGMENTS}

These studies were supported by Fundação de Amparo à Pesquisa do Estado de São Paulo (FAPESP, 05/55237-9).

\section{RESUMO}

Os aloantígenos de neutrófilos estão associados a várias condições clínicas como neutropenias imunes, insuficiência pulmonar relacionada à transfusão (TRALI), refratariedade à transfusão de granulócitos, e reações transfusionais febris. $\mathrm{Na}$ última década, foi observado considerável progresso na caracterização dos aloantígenos envolvidos nestas condições clínicas. Atualmente sete antígenos estão incluídos em cinco sistemas de antígenos de neutrófilo humano (HNA). Os antígenos HNA-1a, HNA-1b e HNA-1c foram identificados como formas polimórficas do receptor Fc $\gamma$ RIIIb (CD16b), codificados por três alelos. Recentemente, a estrutura primária do antígeno HNA-2a foi elucidada e a glicoproteína carreadora do antígeno foi identificada como um membro da superfamília Ly-6/uPAR e designada como CD177. O antígeno HNA-3a está localizado em uma glicoproteína de 70-90 kDa, entretanto sua base molecular ainda é desconhecida. Finalmente, os antígenos HNA-4a e HNA-5a são resultantes de mutações de um único nucleotídeo nas subunidades $\alpha_{\mathrm{M}}(\mathrm{CD} 11 \mathrm{~b})$ and $\alpha_{\mathrm{L}}$ (CD11a) das moléculas de adesão de leucócitos ( $\beta_{2}$ integrinas). A caracterização molecular e bioquímica dos antígenos neutrofílicos permitiu a expansão das ferramentas diagnósticas pela introdução de técnicas de genotipagem e imunoensaios para a identificação de anticorpos. Novos estudos envolvendo a imunologia de granulócitos serão de grande valor para a prevenção e tratamento de reações transfusionais e doenças imunes causadas por aloanticorpos de neutrófilos.

Palavras-chave: antígenos de neutrófilos, transfusão sanguínea, aloimunização, reação transfusional, neutropenia. 


\section{REFERENCES}

Bauer S, Abdgawad M, Gunnarsson L, Segelmark M, Tapper H and Hellmark T. 2007. Proteinase 3 and CD177 are expressed on the plasma membrane of the same subset of neutrophils. J Leukoc Biol 81: 458-464.

BUX J. 1999. Nomenclature of granulocyte alloantigens. ISBT Working Party on Platelet and Granulocyte Serology, Granulocyte Antigen Working Party. Transfusion 39: 662-663.

BUX J. 2001. Granulocyte immunology. Wien Klin Wochenschr 113: 799-805.

BUX J. 2008. Human neutrophil alloantigens. Vox Sang 94: $277-285$.

BUX J ET AL. 1993. Analysis of granulocyte-reactive antibodies using an immunoassay based upon monoclonalantibody-specific immobilization of granulocyte antigens. Transf Med 3: 157-162.

BUX J ET AL. 1995. NA gene frequencies in the German population, determined by polymerase chain reaction with sequence-specific primers. Transfusion 35: 54-57.

Bux J, Behrens G, JÄger G And Welte K. 1997a. Diagnosis and clinical course of autoimmune neutropenia in infancy: Analysis 240 cases. Blood 89: 1027-1034.

Bux J, Stein El, Bierling P, Fromont P, Clay M, StronceK D AND SANTOSO S. 1997b. Characterization of a new alloantigen ( $\mathrm{SH}$ ) on the human neutrophil Fc $\gamma$ Receptor IIIb. Blood 89: 1027-1034.

Cardone JDB, Bordin JO, Chiba AK, Norcia AMMI AND VIEIRA-FILHO JPB. 2006. Gene frequencies of the HNA-4a and -5a neutrophil antigens in Brazilian persons and a new polymerase chain reaction-restriction fragment length polymorphisms method for HNA-5a genotyping. Transfusion 46: 1515-1520.

Caruccio L, Bettinotti M, Matsuo K, Sharon V AND STRONCEK D. 2003. Expression of human neutrophil antigen-2a (NB1) is increased in pregnancy. Transfusion 43: 357-363.

Clague HD, Fung YL And Minchinton RM. 2003. Human neutrophil antigen-4a gene frequencies in a Australian population, determined by a new polymerase chain reaction method using sequence-specific primers. Transfus Med 13: 149-152.

Davoren A, Curtis BR, Shukman IA, Mohrbacher AF, BUX J, KWIATKOWSKA BJ, MCFARLAND JG AND ASTER RH. 2003. TRALI due to granulocyte-agglutinating human neutrophil antigen $-3 \mathrm{a}(5 \mathrm{~b})$ alloantibodies in donor plasma: a report of 2 fatalities. Transfusion 43: 641-645.

de HaAs M, Kleijer M, van Zwieten R, Roos D AND
VON DEM BORNE AE. 1995. Neutrophil Fc $\gamma$ RIIIb deficiency, nature and clinical consequences: a study of 21 individuals from 14 families. Blood 86: 2403-2413.

de HaAs M, Muniz-Dias E, Alonso LG, VAn der Kolk K, Kos M, Buddelmeijer L, Porcelijn L AND VON DEM BORNE AE. 2000. Neutrophil antigen $5 \mathrm{~b}$ is carried by a protein, migrating from 70 to $95 \mathrm{kDa}$, and may be involved in neonatal alloimmune neutropenias. Transfusion 40: 222-227.

Decary F, Verheught FWA ANd VAN HELden-HenNINGHEIM L. 1979. Recognition of a non-HLA-ABC antigen present present on $\mathrm{B}$ and $\mathrm{T}$ lymphocytes and monocytes only detectable with the indirect immunofluorescence test. Vox Sang 36: 150-158.

Fung L, Pitcher LA, Willett Je, Reed C, Mison L, Bux J, Eiber G AND Minchiton RM. 2003. Alloimmune neonatal neutropenia linked to anti-HNA-4a. Transfus Med 13: 49-52.

Göhring K, WolfF J, Doppl W, SChMidT KL, FENChel K, Pralle H, Sibelius U ANd Bux J. 2004. Neutrophil CD177 (NB1 gp, HNA-2a) expression is increased in severe bacterial infections and polycythaemia vera. Br J Haematol 26: 252-254.

Goldschmeding R, van Dalen CM, Faber N, Calafat J, Huizinga TW, VAN DER Schoot CE, CleMENT LT AND VON DEM BORNE AE. 1992. Further Characterization of the NB1 antigen as a variably expressed 56-62 kDa GPI-linked glycoprotein of plasma membranes and specific granules of neutrophils. Br J Haematol 81: 336-345.

HAN KS AND UM TH. 1997. Frequency of neutrophil-specific antigens among Koreans using the granulocyte indirect immunofluorescence test (GIFT). Immunohematology 13: 15-16.

HAN TH AND HAN KS. 2006. Gene frequencies of human neutrophil antigens $4 \mathrm{a}$ and $5 \mathrm{a}$ in the Korean population. Korean J Lab Med 26: 114-118.

HARTMAN KR AND WRIGHT DG. 1991. Identification of autoantibodies specific for the neutrophil adhesion glycoproteins CD11b/CD18 in patients with autoimmune neutropenia. Blood 78: 1096-1104.

Hibbs ML, Tolvanen M and Carpen O. 1994. Membrane-proximal Ig-like domain of Fc $\gamma$ RIII (CD16) contains residues critical for ligand binding. J Imunnol 152: 4466-4474.

Huizinga TW, Kerst M, Nuyens JH, Vlug A, KleiJer M, VOn DEM Borne AE, Roos D ANd TETTEROo PA. 1989. Binding characteristics of dimeric IgG subclass complexes to human neutrophils. J Immunol 142: 2359 2364. 
Huizinga TW, Kleijer M, TetTeroo PA, von Roos D AND VON DEM BORNE AE. 1990a. Biallelic neutrophil Na-antigen system is associated with a polymorphism on the phosphor-inositol-linked Fc gamma receptor III (CD16). Blood 75: 213-217.

Huizinga TW, KuiJPers RWA, Kleijer M, Schulpen TW, Cuypers HTM, RoOS D AND VON DEM BORNE AE. 1990b. Maternal genomic FcRIII deficiency leading to neonatal isoimmune neutropenia. Blood 76: 19271932.

Kissel K, Hofmann C, Gittinger FS, Daniels G And BUX J. 2000. HNA-1a, HNA-1b, and HNA-1c (NA1, $\mathrm{NA} 2, \mathrm{SH})$ frequencies in African and American Blacks and in Chinese. Tissue Antigens 56: 143-148.

Kissel K, Santoso S, Hofmann C, Stroncek D and BUX J. 2001. Molecular Basis of the neutrophil glycoprotein NB1 (CD177) involved in the pathogenesis of immune neutropenias and transfusion reactions. Eur $\mathrm{J}$ Immunol 31: 1301-1309.

Kissel K, Scheffler S, Kerowgan M And BuX J. 2002. Molecular basis of NB1 (HNA-2a, CD177) deficiency. Blood 99: 4231-4233.

Kline We, Press C, Clay M, Keashen-Schnell M, Hackel E ANd MCCullough J. 1986. Three sera defining a new granulocyte-monocyte-T-Lymphocyte antigen. Vox Sang 50: 181-186.

Koene HR, Kleijer M, Roos D, De HaAs M ANd VON DEM BORNE AE. 1998. Fc $\gamma$ RIIIB gene duplication: evidence for presence and expression of three distinct $\mathrm{Fc} \gamma \mathrm{RIIIB}$ genes in $\mathrm{NA}(1+, 2+) \mathrm{SH}(+)$ individuals. Blood 91: 673-679.

Kuwano St, Bordin JO, ChibA AK, Mello AB, FigueIREDO MS, VieIRA-FILHO JPB, FABRON A AND KERBAUY JR J. 2000. Allelic polymorphisms of human $\mathrm{Fc} \gamma$ receptor IIa and $\mathrm{Fc} \gamma$ receptor IIIb among distinct groups in Brazil. Transfusion 40: 1388-1392.

LALEZARI P AND BERNARD GE. 1965. Identification of a specific leukocyte antigen: another presumed example of 5b. Transfusion 5: 135-142.

Lalezari P, Nussbaum M, Gelman S and Spaet T. 1960. Neonatal neutropenia due to maternal isoimmunization. Blood 15: 236-243.

Lalezari P, Murphy GB and Allen FH. 1971. NB1, a new neutrophil-specific antigen involved in the pathogenesis of neonatal neutropenia. J Clin Invest 50: 1108-1115.

Lin M, Chen CC, WANG CL And Lee HL. 1994. Frequencies of neutrophil-specific antigens among Chinese in Taiwan. Vox Sang 66: 274.
Matsuo K, Lin A And Procter JL. 2000. Variations in the expression of granulocyte antigen NB1. Transfusion 40: 654-662.

McCullough J ET AL. 1988. Granulocyte serology. A clinical and laboratory guide. Chicago, American Society of Clinical Pathologists Press.

Moritz E, Chiba AK, Pinotti F, Yamamoto M And BORDIN JO. 2007. Características fenotípicas do antígeno de neutrófilo humano HNA-2a (NB1, CD177) em indivíduos brasileiros. Rev Bras Hematol Hemoter 29: 343.

Norcia AM, Kimura EY, Chiba AK, Moritz E, YAMAMOTO M AND BoRdin JO. 2006. HNA-1a, -1b, -2a, $-3 \mathrm{a}$ and $-4 \mathrm{a}$ frequencies in Brazilian persons. Blood 108: $36 \mathrm{~b}$.

OHto H AND Matsuo Y. 1989. Neutrophil-specific antigens and gene frequencies in Japanese. Transfusion 29: 654.

Ory PA, Goldstein IM, KWOH EE AND Clarkson SB. 1989. Characterization of polymorphic forms of Fc receptor III on human neutrophils. J Clin Invest 83: 1676-1681.

RaVetch JV AND Perussia B. 1989. Alternative membrane forms of FcRIII (CD16) on human natural killer cells and neutrophils. J Exp Med 170: 481-497.

SACHS UJ ET AL. 2004. Human alloantibody anti-Mart interferes with Mac-1-dependent leucocyte adhesion. Blood 104: 727-734.

Sachs UJ, Reil A, BAuer C, Bux J, Bein G And SANTOSO S. 2005. Genotyping of human neutrophil antigen5a (OND). Transfus Med 15: 115-117.

SACHS UJ ET AL. 2007. The neutrophil-specific antigen CD177 is a counter-receptor for endothelial PECAM-1 (CD31). J Biol Chem 282: 23603-23612.

Simser S, VAN Der Schoot CE, DaAms M, Huiskes E, Clay M, McCullough J, VAn Dalen D, StronCEK D AND VON DEM BORNE AE. 1996. Molecular characterization of antigenic polymorphisms (ONDa and MARTa) of the $\beta_{2}$ family recognized by human leucocyte alloantisera. Blood 88: 1350-1358.

StefFensen R, GÜlen T, VARMing K AND Jersild C. 1999. Fc $\gamma$ RIIIB polymorphism: evidence that NA1/NA2 and $\mathrm{SH}$ are located in two closely linked loci and that the $\mathrm{SH}$ allele is linked to the NA1 allele in Danish population. Transfusion 39: 593-598.

STRONCEK D. 2004. Granulocyte antigens and antibody detection. Vox Sang 87: 91-94.

StronceK D, Skubitz KM And McCullough JJ. 1990. Biochemical characterization of the neutrophil-specific antigen NB1. Blood 75: 744-755. 
TANigushi K, Kobayashi M, Harada H, HiraOKa A, TANihiro M, TAKATA N AND Kimura A. 2002. Human neutrophil antigen-2a* expression on neutrophils from healthy adults in western Japan. Transfusion 42: 651-657.
VAn Leeuwen A, Eernise JG AND VAn Rood JJ. 1964. A new leukocyte group with two alleles: leukocyte group five. Vox Sang 9: 431-437. 